\title{
Distribution and population dynamics of Calamus nambariensis Becc. - An endemic and threatened cane of
}

\section{Assam}

\author{
Kishor Deka, S.K. Borthakur, Bhaben Tanti* \\ Department of Botany, Gauhati University, Guwahati - 781014, Assam, India.
}

Received: 2017-10-25; Accepted: 2017-10-25

\begin{abstract}
Rattans are prickly climbing palm which comprise more than fifty percent of the total palm taxa found in India. This non-timber forest product has great economic importance in handicraft and furniture making because of its richness in fiber, with suitable toughness and easy for processing. The rattan resources have depleted very fast in recent years due to over exploitations, uncontrolled harvesting and deforestation. High demand for these resources has led towards the exhaustion in many rattan-producing areas. C. nambariensis is a high-quality cane, considered as endemic and threatened to the North-eastern region of India. Subsequently this species of cane has been depleting very fast due to several human impacts such as habitat fragmentation and over-exploitation which hinder the sufficient development of the plant in its natural condition. So, it is urgently needed to find out the habitat distribution and population status of $C$. nambariensis for making strategy to improve its conservation status. The present study reveals the occurrence of C. nambariensis only in two pockets of Assam viz, Nambor Reserve Forest of Golaghat district and Gibbon Wildlife Sanctuary of Jorhat district, Assam (India). The density, frequency and abundance of this species in Nambor Reserve Forest for last three years were found to decline as 1.038, 83.75, 1.23; 0.888, 78.75, 1.122 and 0.8, $76.25,1.057$ respectively. This declining rate depicts the near extinction of the species.
\end{abstract}

Keywords: C. nambariensis, RET plant, Distribution, Population dynamics

\section{Introduction}

Rattans are the most important non-timber forest products (after bamboo) in the tropical and subtropical counties of Asia and Africa. This spiny climbing palms belonging to the subfamily Calamoideae of the Arecaceae. There are over 600 different species of rattan belonging to 14 genera distributed throughout the old-world tropics including equatorial Africa, South Asia, Southern China, the Malay Archipelago, Australia and the Western Pacific (Dransfield \& Manokaran, 1994; Uhl \& Dransfield, 1987). India has a good representation of rattans with 5 genera and 70 species which are distributed along the wet evergreen forests of the Western Ghats of Peninsular India, sub-Himalayan tracts of the North-Eastern Himalaya region and the Andaman and Nicobar Islands (Uma Shaanker et al., 2004). Although four genera are known to occur in India, only the genus Calamus represents the canes (rattans) from the southern region in the NorthEast India and Western Ghats (Basu, 1985). The North-Eastern Himalaya comprising the states of Assam, Arunachal Pradesh, Manipur, Meghalaya, Mizoram, Nagaland, Sikkim and Tripura, is considered to be one of the major hot-spots of rattan diversity in India and accounts for about 50\% of the total rattan flora in India (Uma Shaanker et al., 2004). Rattans form one of the major non-wood forest products in international trading.

\section{*Corresponding Author:}

Dr. Bhaben Tanti, Ph.D.,

Professor, Department of Botany,

Gauhati University, Guwahati 781014

Assam, India.

E-mail: btanti@gauhati.ac.in
Approximately 700 million people trade or use rattan for different purposes worldwide mainly for furniture and cottage industries. In the last century, rattan canes have become one of the world's most valuable non-timber forest products (Ros-Tonen, 2000). Rattans are important sources of income and employment for millions of people all over the world directly or indirectly. In India, rattan industries alone provide jobs for 200,000 people (Manokaran, 1990) and its contribution is about 25 $35 \%$ of the total household income of the tribal communities in North Eastern India. The global trade and subsistence value of rattan and its products is estimated at over US\$7,000 million per annum (Pabuayan, 2000). Due to overexploitation, habitat degradation and low regeneration capacity, the rattan resources of the world are under serious threat. In Malaysia, Sumatra and the Philippines, most important commercial rattan species are already threatened due to overexploitation (Dransfield, 1992). It is estimated that around 117 species of rattans are treated as threatened to some degree (Walter \& Gillet, 1998).

Calamus nambariensis Becc. is commonly known as 'boka-bet' belongs to the family Arecaceae. This species is considered as $1^{\text {st }}$ class category of cane and is commonly used in furniture industries, minor cottage industries and house making purposes. This 
spiny palm of rattan has considered as endemic and threatened to the North-eastern region of India (Basu, 1992; Thomas \& Haridasan, 1997). Subsequently this species has also been listed as endemic and threatened to North East India during CAMP workshop 2003. C. nambariensisis was first described by $O$. Beccari based on the specimen collected by G. Mann from Nambar forest of Assam in 1900. After G. Mann's report (1900) from Nambor Reserve forest of Assam, no further study was conducted on the distribution as well as population status of this species in Assam as well as North East India. So the present investigation is to find out the distributional ranges of $C$. nambariensis and their changing population pattern in Assam of North east India, which will be helpful in formulating further logical steps for conservation of this species.

\section{Material and Methods}

\section{Plant material}

Scandent, rather robust, clump forming, clustering, climbing up to 40-67 m. Leaf with cirrus $389-465$ $\mathrm{cm}$, leaf sheath $25-32 \mathrm{~cm}$ long, stem with leaf sheath $13-15 \mathrm{~cm}$ in diam., without sheath $5.5-7 \mathrm{~cm}$ in diam., diameter progressively increased from base to apex, colour of leaf sheath in juvenile stage grey which turn to yellowish green in mature plant. Two types of spine present in leaf sheath. The space between the large spines have scattered smaller spines. Large spine deflexed with broad and concavo- convex swollen base, scares of adpressed immature spines prominent on maturity. Knees prominent; flagella absent; petioles very short; rachis slightly triangular at the basal part and quadrangular at the distal part in cross section, with 13-36, lanceolate leaflets per side, these irregularly or regularly arranged, bristly along the margins; cirri present, 150- $167 \mathrm{~cm}$ long. Inflorescences to 117 $170 \mathrm{~cm}$ long, flagellate; bracts tubular; fruits borne on short stalks, ovoid with distinct nipple, $2.4 \mathrm{~cm}$ long and $2.5 \mathrm{~cm}$ diameter, with channeled scales.

\section{Study area}

Assam is a state of India which is located at the North East part with an area of 78, $523 \mathrm{sq} . \mathrm{km}$. and lies between $24^{\circ} 09^{\prime} \mathrm{N}-27^{\circ} 58^{\prime} \mathrm{N}$ Latitude and $89^{\circ}$ $42 / \mathrm{E}-96^{\circ} 01 / \mathrm{E}$. Assam of North East India is also one of the 12 Mega biodiversity hotspots of the world. Topographally the state is divided into three parts, viz. Brahmaputra valley, Surma valley and the mountains Assam ranges. The state has subtropical climate with mean annual rainfall varying from $1500 \mathrm{~mm}$ to $3750 \mathrm{~mm}$. The geographical location with two main rivers i.e. the Brahmaputra and the Barak having a network of river systems along with their numerous tributaries, geology, fertile-living soil, tropical monsoon climate. Based on the floristic composition of the state of Assam the vegetation of it are found to be several types including Tropical Moist Evergreen forest, Tropical
Semi-Evergreen forest and dry deciduous forest (Chowdhury, 2005). Besides these the Degraded and Scrubland Grassland and Savannahs, Wetlands, Bamboo Forests and waste lands are also rich in their vegetation.

Identification of hot-spots of rattan species richness and survey of $C$. nambariensis in Assam

Data on the distribution of rattan species in the forest of Assam were obtained from flora, herbaria, and other published sources including forest department records and other archival material. We surveyed the specific locations of Assam for our targeted species. The survey was conducted during the year of 2013-2015. The latitude and longitude, elevation of the ranges of occurrence as well as the associated species of $C$. nambariensis was also recorded. And finally a distributional map was also prepared on the basis of reported locations.

\section{Study of population dynamics}

Finding presence point data of Calamus nambariensis is difficult because of the declining populations. The occurrence points of $C$. nambariensis were identified based on the field surveys in Assam of North East region of India. Species occurrence point data was collected through frequent field survey of Nambor Reserve Forest of Assam during the period of 2013-2015. Thus, to study the changes of population status, a wide range of repeated field study was made to the study site for three years. Total population of the species was ascertained through direct count of all the individuals considering saplings ( $>1 \mathrm{~m}$ height) and matured individuals ( $\geq 1.37 \mathrm{~m}$ height) in each $50 \mathrm{~m} \times 50 \mathrm{~m}$ grid of occurrence within the predicted localities (Baruah et al., 2016; Deka et al., 2017; Fourcade et al., 2014; Giles et al., 2014).

The density, frequency and abundance of the plant species was calculated with the following formulas,

\section{Density $=\underline{\text { Total number of Individuals in all sampling units }}$ Total number of sampling units studied \\ Frequency $=$ Number of sampling units in which the species occur $\times 100$ Total number of sampling units studied \\ Abundance $=$ Total number of individuals of a species in all quadrats}

\section{Result}

Distribution of $C$. nambariensis in Assam

After a long period of survey in different parts, it was observed that the species $C$. nambariensis was restricted only in two pockets of Assam. The population of this species is restricted and confined only in Nambor Reserve Forest of Golaghat district and Gibbon Wildlife Sanctuary of Jorhat district of Assam. Gibbon Wildlife Sanctuary is newly reported location of C. nambariensis from Assam (Fig. 1). 
The Nambor reserve forest of Assam located in Golaghat district of Assam with an area of 78, 523 sq. $\mathrm{km}$. and lies between $26^{\circ} 09^{\prime} \mathrm{N}-27^{\circ} 58^{\prime} \mathrm{N}$ and $93^{\circ} 42^{\prime} \mathrm{E}-96^{\circ} 01^{\prime} \mathrm{E}$. The forest type of Nambor is tropical Semi-evergreen with pockets of pure Evergreen, interspersed with small forest marshes. This forest is mainly dominated by medium or short trees where large numbers of shrubs are entangled by lianas and stragglers. Ground vegetation is occupied by bulbous, rhizomatous plants scattered in association with herbaceous angiosperms; ferns and fern allies. Moreover, Nambor forest is adorned with luxuriant growth of several epiphytic plants primarily orchids and ferns. Besides, large bamboo and cane thickets are found along the edges of forests and in degraded forest as secondary growth. The common Associated trees of $C$. nambariensis are Elaeocarpus sphaericus, Terminalia chebula, Mallotus ferrugineus, Mangifera sylvatica, Antidesma bunius, Beilschmiedia fagifolia, Cinnamomum bejolghota, Castanopsis armata, Aesculs assamica, Actinodaphne obovata, Garcinia kydia, C. flagellum, C. erectus, Zalacca secunda, Toona ciliate and Vatical lancaefoli (Fig. 2).

The newly reported location of $C$. nambariensis is Gibbon Wildlife Sanctuary of Jorhat district, which lies between $24^{\circ} 09^{\prime} \mathrm{N}-27^{\circ} 58^{\prime} \mathrm{N}$ Latitude and $89^{\circ}$ $42 / \mathrm{E}-96^{\circ} 01^{\prime} \mathrm{E}$ with an area of $19.49 \mathrm{~km} 2$. The area falls under Indo-Burma Biodiversity Hotspot situated at an elevation of 100-120 m (Chetia \& Kalita, 2012). The Hoollongapar Gibbon Sanctuary or Gibbon Wildlife Sanctuary the home of India's only gibbons - the hoolock gibbons, is an isolated protected area of evergreen forest located in Jorhat, Assam, India. The forest is classified as "Assam plains alluvial semi-evergreen forests" with some wet evergreen forest patches (Champion and Seth, 1968). The sanctuary is completely surrounded by tea gardens and a few villages near to forest as fringe village. This Wildlife Sanctuary is adorned with luxuriant and gregarious growth of broad leaved lofty tree species of angiosperms along with number epiphytes including orchids and ferns. The floristic composition contains a few tall trees along with some medium sized form the canopy and merge with large shrubs intermingle with climbers and dense undergrowth of low shrubs and herbs. The common plants found to be associated with $C$. nambariensis in Gibbon Wildlife Sanctuary are Dipterocarpus macrocarpus, Mangifera sylvatica, Shorea assamica, Mesua ferrea, Gynocardia odorata, Garcinia acuminate, Garcinia kydia, Magnolia griffithii, Phoebe goalparensis, Litsea assamica, Terminalia myriocarpa, Vatica lancaefolia, C. floribunda, Castanopsis purpurella, C. tribuloides, Beilschmiedia brandisii, Ficus benjamina and Ardisia paniculatum.

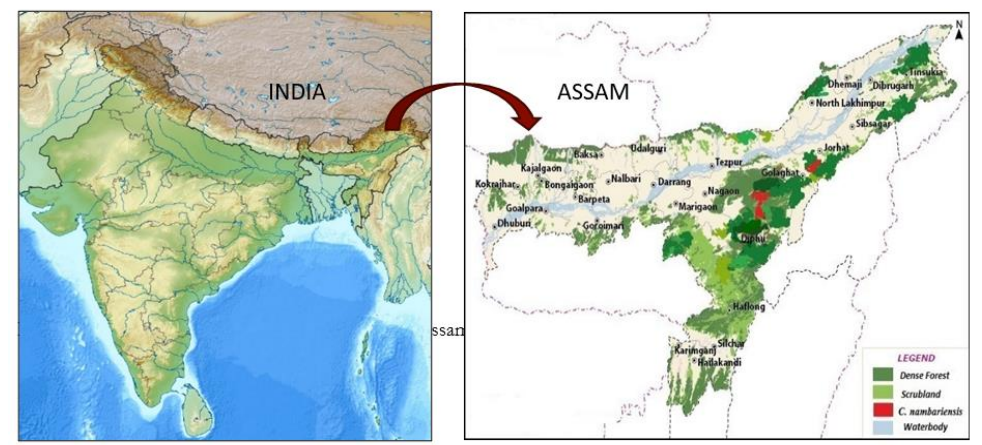

Figure 1. Distributional map of C. nambariensis in Assam (India)

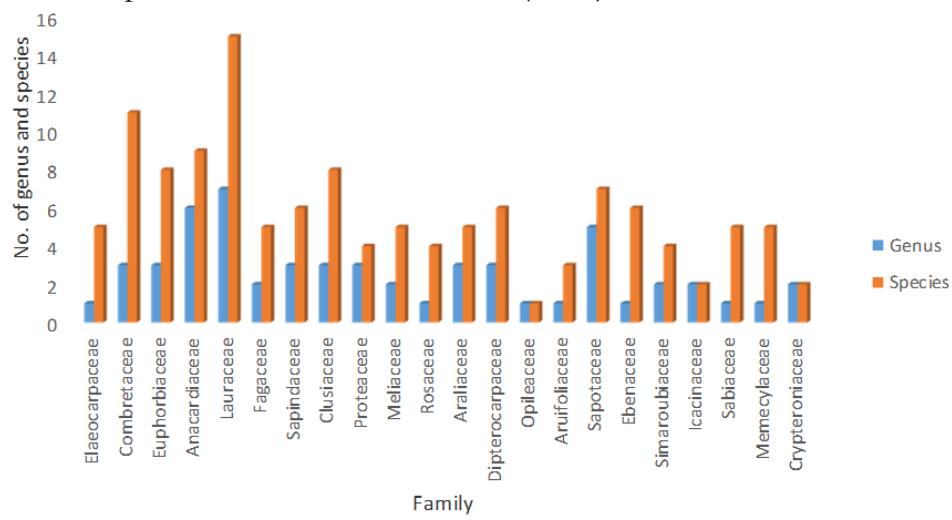

Figure 2. Graphical representation of tree species composition in Nambor Reserve Forest

Population dynamics of $C$. nambariensis in the study sites

Broad-scale destruction and fragmentation of native vegetation is commonly visible phenomenon throughout the world (Kluge et al., 2006). For conservation strategies, species with a limited distribution are of greater importance than with a wide distribution. Habitat destruction and 
fragmentation are the root causes of related conservation problems. In our present investigation it was observed that Gibbon Wildlife Sanctuary was isolated and exploitation of rattan as well as other plant resources are comparatively very less than other Protected areas. So for study of population dynamics of $C$. nambariensis we considered different plots of Nambor Reserve Forest, which are disturbed and destroyed in extreme cases due to shifting cultivation by the tribal communities of the nearby villagers in this Reserve Forest. We considered consecutive three years for same month (April) for studying the changes of community structure to the study sites. Through extensive field visits, the population size of the species was recorded considering the density, frequency of occurrence and abundance of $C$. nambariensis. We also reported associated tree species of $C$. nambariensis as well as canopy coverage of the study sites using densiometer. A total of 16 quadrates were observed in each site. The observation tabulated below depicts the mean density, frequency and abundance of $C$. nambariensis in Nambor Reserve Forest for first year as 1.038, 83.75, 1.23; for second year as $0.888,78.75,1.122$ and for third year as $0.8,76.25,1.057$ respectively, showing a significant decrease in population pattern (Table 1; Fig. 3). The canopy coverage of $C$. nambariensis in the studied area was also found to be remarkably decreased (Fig. 4).

Table 1. Year wise assessment of community structure of $C$. nambariensis

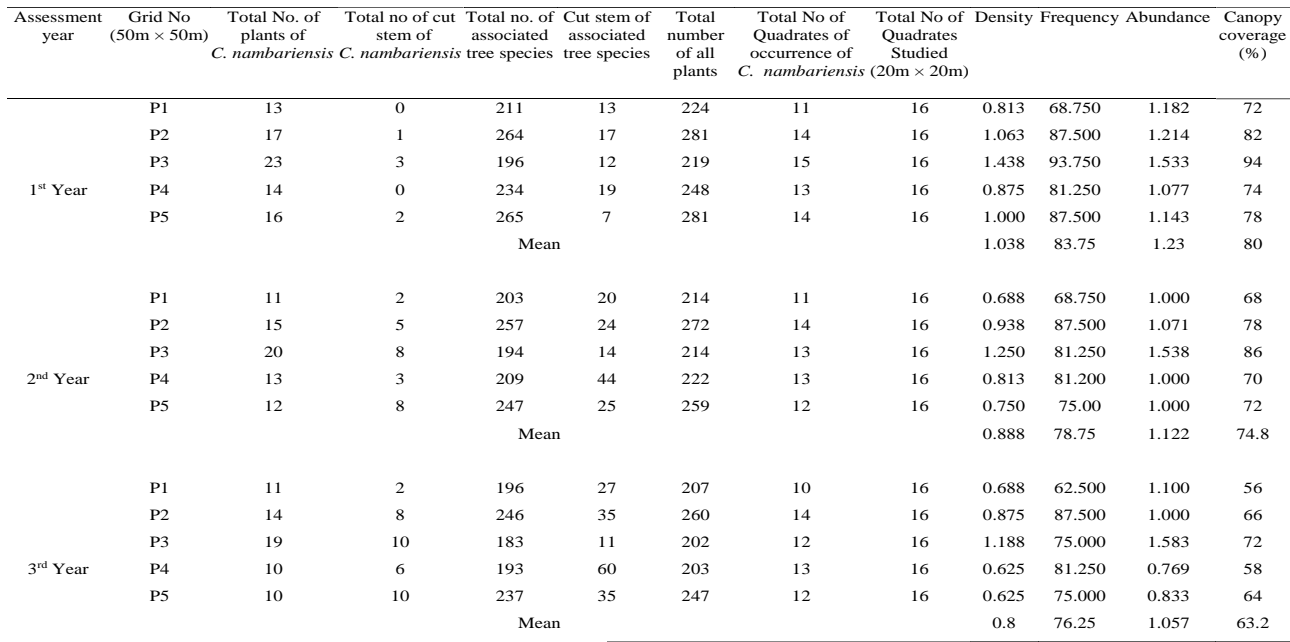

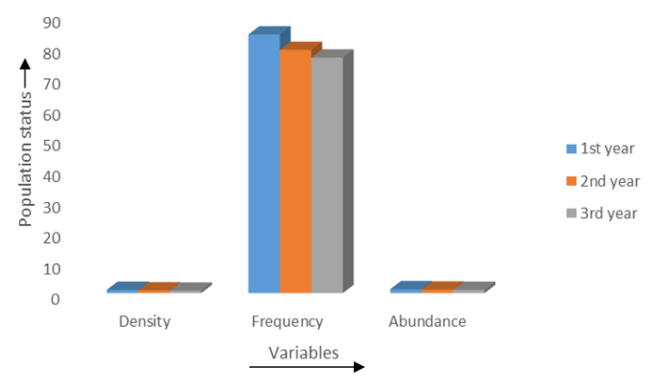

Figure 3. Three-year assessment of density, frequency and abundance of $C$. nambariensis in Nambor reserve forest

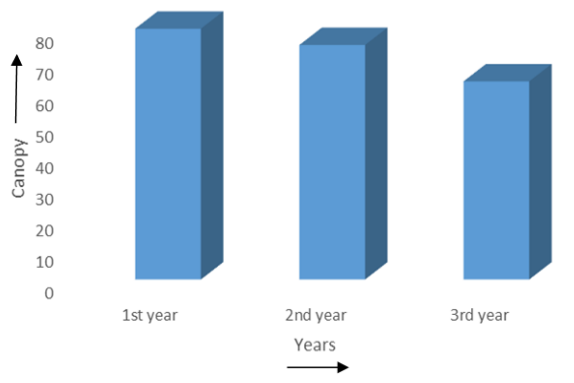

Figure 4. Changing of canopy pattern in the study site

The correlation matrix showed the relationships among the analyzed density, frequency and abundance of $C$. nambariensis for the assessment years (2013-2015) was presented in Table 2. In our present investigation, there were significantly positive correlations between density, frequency and abundance in $1^{\text {st }}$ year. Significant positive correlations between density, frequency $(0.840)$ and density, abundance (0.919) were shown at the 0.01 level, which indicates that positively correlated. Significant positive correlations between frequency and abundance $(0.558)$ were shown at the 0.05 level, which indicates that both are directly proportional to each other means among these compounds if one increases other also increases. In $2^{\text {nd }}$ year, significant positive correlations between density and abundance were shown at the 0.01 level, which indicates that positively correlated and significant positive correlations between frequency and density (0.632) were shown at the 0.05 level, which indicates that both are directly proportional to each other means among these compounds if one increases other also increases. In the last year study it was observed that frequency and density; and abundance and density showed positive correlation whereas abundance and frequency $(-0.250)$ showed negative correlation, suggesting that if abundance is increased than frequency is decreased or vice-versa. 
Table 2. Correlation between density, frequency and abundance of C. nambariensis

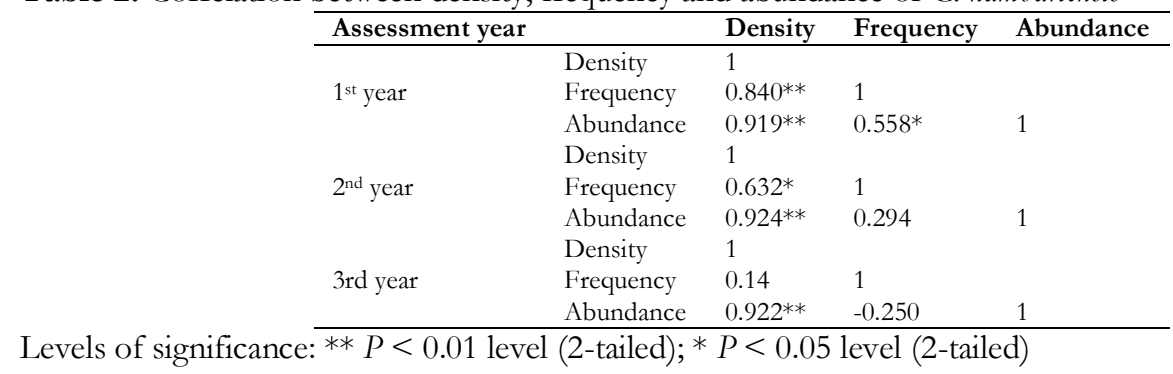

\section{Discussion}

The rattan resources have depleted fast in recent years due to over exploitations and poor management including almost complete removal of stems from the forest during harvesting or shifting cultivation. Consequently, steady loss of forest habitat due to urbanization and industrialization is also posing a serious threat to rattan supply. High demand for these resources, coupled with uncontrolled harvesting and deforestation, has led the resources towards the exhaustion in many rattan-producing areas (Supardi et al., 1999). To cope with the increasing global demand for rattan, there is an urgent need for sustainable management of rattan resources.

Potential habitat of $C$. nambariensis was defined as a habitat which bears a set of ecological conditions that allows the species to persist and regenerate (Grinnell, 1917). Earlier records from secondary sources showed that the occurrence of the $C$. nambariensis from Nambor Reserve Forest of Golaghat district, India being limited to only a few populations (Haridasan et al., 2002; Thomas \& Haridasan, 1997). However, during our extensive field survey we have reported one new locations of C. Nambariensis i.e., Gibbon Wildlife Sanctuary of Assam. Surprisingly, the populations discovered so far revealed poor population strength. The main cause for the smaller size in the number of individuals in each population is either over exploitation or direct or indirect effect of various anthropogenic activities. However, the population status could be changed through increasing its number of individuals in its suitable natural habitat either through reinforcement or reintroduction.

In our long term base study, it was observed that Density, Frequency and Abundance is significantly decreased along with canopy coverage in Nambor reserve Forest. It was found that the main cause of decreasing species was over exploitation by the local people for the means of their house hold purpose. Associated plant also plays an important role for the development and sustainability of a species. A total of 126 tree species of 56 genera of 17 families was found to be dominantly in our study sites of Nambor Reserve, among which family Lauraceae contain highest species (15) whereas Opileaceae having only one species. It was observed that decreasing canopy coverage of the associated tree species results to decrease of this cane species (Fig. 5). Nambor Reserve Forest is surrounded by many Karbi villages, where due to intervention of local people the forest is much affected day by day. Shifting cultivation which is the alternative source of agriculture of the local people is hindering the population of $C$. nambariensis, which ultimately cause an undesirable threat to the developing population structure. Considering the RET status and dwelling threats of the plant, strict measures should be adopted and applied for the conservation through reinforcement of this cane species.

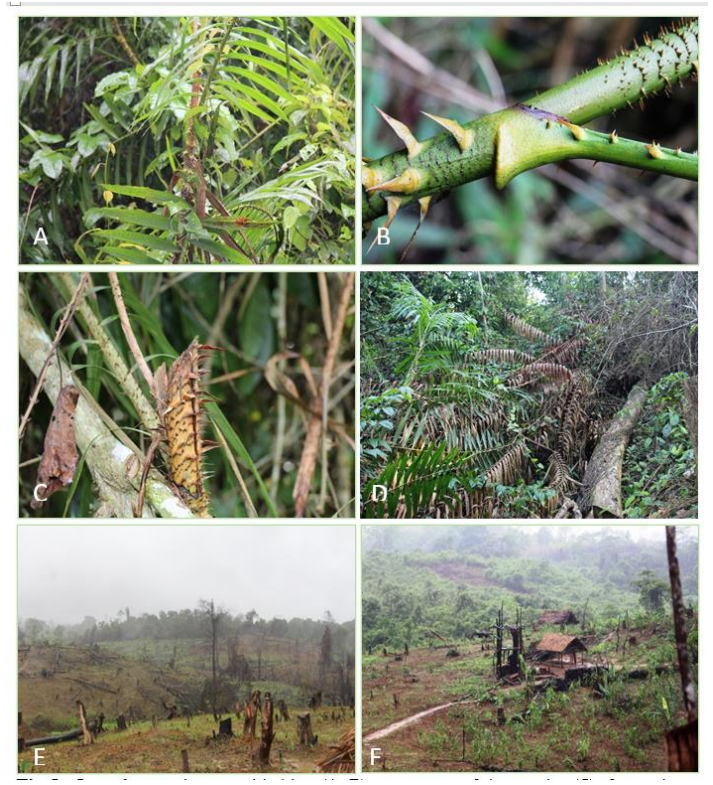

Fig 5: C. nambariensis in natural habitat (A, B); cut stump of the species (C); forest destruction and shifting cultivation in Numbar Reserve Forest (D, E, F).

\section{Acknowledgements}

Funding support received from Department of Biotechnology (DBT), Govt. of India for the research project entitled "Preventing extinction and improving conservation status of threatened plants through application of biotechnological tools" vide sanction number BT/Env/BC/01/2010, dt.23.03.2012 is greatly acknowledged. $\mathrm{KD}$ also thanks to UGC-RGNF, Govt. of India for research fellowship. 


\section{References}

1. Baruah PS, Borthakur SK, Tanti B, Conservation of Mesua assamica (King and Prain) Kosterm. - an endangered plant of Assam, NeBIO- An International Journal of Environment and Biodiversity, 2016, 7(1): 1722.

2. Beccari O, Asiatic Palms - Lepidocaryoideae Part I. The species of Calamus. Annals of Royal Botanical Garden, Calcutta, 1908, 11 (1): 1-518.

3. Basu SK, Conservation status of Rattan in India. In: Chand BS \& Bhat KM (eds). Rattan Management and Utilization. KFRI, Kerala \& IDRC, Canada, 1992, pp. 67-75.

4. Basu SK, The present status of Rattans Palms in India-An overview. In: Proceedings Rattan Seminar (Wong and Manokaram, eds), Kuala Lumpur, 1985, pp. 77- 94 .

5. Champion HG and Seth SK, A Revised Survey of Forest Types of India, Manager of Publications, India, 1968 ,

6. Chetia P and Kalita DK, Diversity and distribution of spiders from Gibbon Wildlife Sanctuary, Assam, India. Asian Journal of Conservation Biology, 2012, 1(1): $5-15$.

7. Chowdhury S, Assams Flora, A partial documentation of the project "Environmental Atlas of Assam" ASTEC, 2005.

8. Deka K, Baruah PS, Sarma B, Borthakur SK, Tanti B, Preventing extinction and improving conservation status of Vanilla borneensis Rolfe-A rare, endemic and threatened orchid of Assam, India. Journal for Nature Conservation, 2017, 37: 3946.

9. Dransfield J and Manokaran N, Plant resources of South-East Asia, Rattans, no. 6. Prosea Foundation, Bogor, 1994.

10. Dransfield J, The ecology and natural history of rattans; in: A Guide to the cultivation of Rattans, R. W. A. Wan, J. Dransfield and N. Manokaran (Eds), pp. 27-34. Forest research institute, Malaysia 1992.

11. Fourcade Y, Engler JO, Rodder D, Secondi J, Mapping species distributions with MAXENT using a geographically biased sample of presence data: A performance assessment of methods for correcting sampling bias. PLoS One, 2014, 9: 97-122.

12. Giles JR, Peterson AT, Busch JD, Olafson PU, Scoles GA, Bavey R, Pound JM, Kammlah DM, Lohmeyer KH, Wagner DM, Invasive potential of cattle fever ticks in the southern United States. Parasites \& Vector, 2014, 7: 189.
13. Grinnell J, Field tests of theories concerning distributional control. The American Naturalist 1917, 5: 115-128.

14. Haridasan K, Sarma A, Hegde SN, Bhuyan LR, Field Manual for Propagation of Canes in Arunachal Pradesh. State forest Research Institute, Itanagar, 2002.

15. Kluge J, Kessler M, Dunn RR, What drives elevational patterns of diversity? A test of geometric constraints, climate and species pool effects for pteridophytes on an elevational gradient in Costa Rica. Global Ecology and Biogeography, 2006, 15: 358371.

16. Manokaran N, The State of Bamboo and Rattan Trade. Rattan Information Centre Occasional Paper No. 7. RIC, Forest Research Institute, Kepong, Malaysia, 1990, $39 p$.

17. Pabuayan I, addressing rattan technology needs for Asia. Paper presented at the XXI IUFRO World Congress. Kuala Lumpur, Malaysia, 2000.

18. Ros-Tonen MAF, The role of non-timber forest products in sustainable tropical forest management. Europian Jurnal of wood and Wood products, 2000, 58:196-201.

19. Supardi MNN, Khali H, Razali M, Considerations in rattan inventory practices in the tropics. INBAR Technical Report 14. International Network, for Bamboo and Rattan, Beijing, China, 1999, 57 p.

20. Thomas S and Haridasan K, Calamus nambariensis Becc. -an interesting rattan palm from Arunachal Pradesh. Arunachal Forest News, 1997, 15: 29-30.

21. Uhl NW and Dransfield J, "Genera Palmarum; a classification of palms based on the work of Harold, E., Moor E.Jr." Allan Press, Lowrence, KS, 1987.

22. Uma Shaanker R, Ganeshaiah KN, Srinivasan KV, Rao R, Hong LT, Bamboo and Rattans of the Western Ghats: Population biology, Socio-economic and Conservation Strategies. ATREE, UAS, IPGRI, Bangalore, 2004.

23. Walter KS and Gillett HJ, IUCN Red List of Threatened Plants. Compiled by the World Conservation Monitoring Centre. IUCN - The World Conservation Union, Gland, Switzerland and Cambridge, UK, 1998.

\section{Cite this article as:}

Kishor Deka, S. K. Borthakur and Bhaben Tanti. Distribution and population dynamics of Calamus nambariensis Becc. -an endemic and threatened cane of Assam. Annals of Plant Sciences 6.12 (2017) pp. 1829. 1834.

doi: http://dx.doi.org/10.21746/aps.2017.6.12.5

\section{Source of support: Nil \\ Conflict of interest: Nil}

